\title{
空気集熱式太陽熱暖房システムの簡易設計法に関する研究 SIMPLIFIED DESIGN METHOD FOR AIR-BASED SOLAR HEATING SYSTEM
}

\author{
北野博 亮*, 相良和 伸** \\ Hiroaki KITANO and Kazunobu SAGARA
}

\begin{abstract}
The purpose of this research is to develop a simplified design method for an air-based solar heating system with a rock bed storage tank. In this paper, several equations to determine capacity of rock bed and collector area according to design conditions, are obtained. They are derived from results of system simulations and the necessary and sufficient capacity of rock bed is calculated by using the equations. And the design method using several simple equations is presented. And as a result of system simulations under various design conditions, it is found that the simplified design method allows to design appropriate heating system under ordinary design conditions.
\end{abstract}

Keywords : solar energy, heating, rock bed, simplified design method 太陽エネルギー, 暖房, 砕石蓄熱槽, 簡易設計法

1.はじめに

一般に太陽熱暖房システムは, 初期投資額を節約できたエネルギ 一費で短期に償却することは容易ではないことから，太陽熱暖房シ ステムの最適設計は非常に重要であると言える.太陽熱暖房システ ムの設計手法1)としては, シミュレーションによる方法等があるが, 設計パラメータの最適な組み合わせを得るためには, 試行錯䛊によ り検討する必要があり，煩雑な作業が必要となる，従って住宅設計 に携わる小規模な設計事務所では対応が難しく，合理的で簡易な設 計手法が必要とされている.

本研究は, 砕石蓄熱槽を有する空気集熱式太陽熱暖房システムに ついて, 合理的な最適設計のための簡易な設計手法の開発を目的と している，本簡易設計法では，設計条件としてのある一日に，集熱 し蓄熱した太陽熱によって，その日の暖房負荷を過不足なく処理で きるシステムを設計目標としている。一般に，太陽熱利用システム の設計では，暖房期間全体の太陽熱依存率等の期間性能を指標とし ており, 設計したジステムの期間性能を f-chart 法")やシミュレーシ ヨン等により求め, 性能や規模が妥当であるかを判断し, 試行錯誤 によりコレクター面積や砕石蓄熱槽容量等を決定している. 本論文 では期間性能については検討していないが, 設計条件としての一日 の気象条件や暖房負荷条件と期間性能との関係をシステムシミュレ ーション等により明らかにすることで, 設計者が目標とするシステ
么の性能から適切な気象条件や暖房負荷条件を決定でき, 本簡易設 計法でも, 期間性能を考慮した設計が可能となると考えている.

既報 2)では，集熱ファンの制御が単純な定風量集熱の場合につい て, 蓄熱槽効率の点で最適な蓄熱槽容量について理論的検討を行い, 集熱風量と最適蓄熱槽容量および一日の蓄熱量の関係を近似的に表 す関係式を示した。

本論文では, 変風量集熱方式の場合について, 集熱温度に応じた 最適蓄熱槽容量について理論的検討を行い, 集熱温度, 最適蓄熱槽 容量および一日の蓄熱量の関係が近似的に得られる関係式を導出し， これらの関係式を用いた簡易設計法を提案する。 またここの簡易設 計法により設計されたシステムの蓄熱・放熱繰返し運転のシステム シミュレーションを行い, 本簡易設計法の適用範囲についても検討 する。

\section{2. 対象システムと設計条件}

对象としたシステムは，その概略を図1に示したような，平板型 コレクター, 砕石蓄熱槽, 室から構成される空気集熱式太陽熱暖房 システムである。ここで, 集熱および放熱のためのファンは, イン バータにより回転数制御がなされるとした．本論文で対象とする変 風量集熱方式は, 定風量集熱方式と比較して初期コストが高くなる が, 定風量集熱方式では集熱温度が暖房に利用できない低温度とな Research Assoc., Dept. of Architecture, Faculty of Engineering, Mie University, M. Eng.

Prof., Dept. of Architectural Engineering, Graduate School of Engineering, Osaka University, Dr. Eng. 


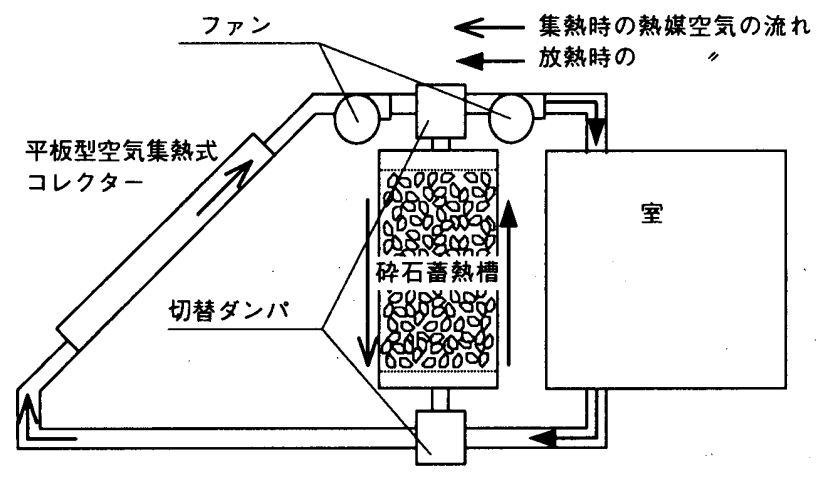

図1 対象システムの概略図

る場合でも，集熱風量を絞ることで暖房に有効な温度で集熱でき， 蓄熱槽からの放熱温度が比較的高温となるため, 放熱側のファンで のエネルギー消費量を削減できると考えている.

一般に，太陽熱暖房システムだけでは冬季の暖房負荷を全て処理 することはできないので, 補助暖房器具が必要である。本研究では, 補助暖房として居室に設置する強制対流式の暖房器具を想定してい るが，設計条件とした日に補助暖房は使用しなくとも負荷を処理で きる太陽熱暖房システムの設計法の検討を行っているので, 本論文 の対象システムの図（図1）には補助暖房器具は示していない.

表 1 には設計条件を示した。ここでは, 気象条件として東京の 2 月 1 日の晴天日を例として検討している.コレクターの方位角を

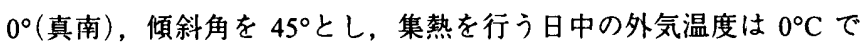
一定であると仮定した。コレクター面への日射量は, Bouguer の直

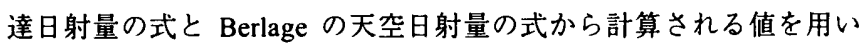
た ${ }^{3)}$. 砕石蓄熱槽は, 熱媒空気の流れ方向が鉛直方向となるように 設置し, 形状は水平断面が正方形の直方体で, 高さは水平断面の辺 の長さの二倍であるとした。蓄熱槽内初期温度は, $20^{\circ} \mathrm{C}$ 一様として いるが,これは暖房時に放熱が完了した時点で, 槽内が暖房設定温 度となっているとしているためである。

\section{3. シミュレーションによる蓄熱槽容量と蓄熱量の関係}

\section{1 シミュレーションのモデル}

集熱·蓄熱特性の把握のため,コレクターのモデルと砕石蓄熱槽の 伝熱モデルを用いて数値計算を行った。このシミュレーションでは, コレクター以外のダクトや蓄熱槽からの熱損失とファンでの発熱や 摩擦による熱取得は相殺されるものと仮定し,これらの影響は無視 している.

\section{(a) コレクター}

変風量集熱の場合の集熱風量は, Hottel-Whillierのコレクター効率 の一次の定義式 ${ }^{11,31}($ 式(1)) と, 集熱量と集熱面に入射する日射量の 比で表される効率の式(式 (2))から集熱効率 $(\eta)$ を消去し, コレクタ 一の出口空気温度 $\left(\theta_{\text {col.out }}\right)$ をコレクター出口空気温度の制御の目標 值（以下では集熱設定温度）( $\left.\theta_{\text {cal ,set }}\right)$ に置き換えた式(3)で計算でき るものとした.

$$
\begin{gathered}
\eta=F^{\prime}(\tau \alpha)_{e}-F^{\prime} K_{c o l} \frac{\left(\theta_{c o l, o u t}+\theta_{c o l . i n}\right) / 2-\theta_{a m b}}{I_{c o l}} \\
\eta=\frac{c_{a} \rho_{a} F a_{c o l}\left(\theta_{c u l . o u t}-\theta_{c o l . i n}\right)}{I_{c u l}}
\end{gathered}
$$

\begin{tabular}{|c|c|}
\hline $\begin{array}{c}\text { 設置位置 } \\
\text { 設定日 } \\
\text { 天候 } \\
\text { 大気透過率 }{ }^{3)} \\
\text { 太陽定数 } \\
\text { 外気温度 } \\
\end{array}$ & $\begin{array}{c}\left.\text { 東京(北緯 } 35.4^{\circ} \text { 東経 } 139.5^{\circ}\right) \\
2 \text { 月 } 1 \text { 日 } \\
\text { 快晴 } \\
0.78 \\
0{ }^{\circ} 1.37 \mathrm{~kW} / \mathrm{m}^{2} \\
\text { (集熱時一定) } \\
\end{array}$ \\
\hline \multicolumn{2}{|c|}{ コレクター } \\
\hline $\begin{array}{l}\text { 方位角 } \\
\text { 傾斜角 }\end{array}$ & $\begin{array}{c}0^{\circ} \quad \text { (真南向き) } \\
45^{\circ}\end{array}$ \\
\hline \multicolumn{2}{|c|}{ 蓄熱槽 } \\
\hline $\begin{array}{c}\text { 槽形状 } \\
\text { 碎石の容皘比熱 } \\
\text { 碎石の等価直径 } \\
\text { 空䏚率 } \\
\text { 初期温度 }\end{array}$ & $\begin{array}{c}1: 1: 2(\text { 熱媒空気流れ方向) } \\
1.92 \mathrm{MJ} /\left(\mathrm{m}^{3} \cdot \mathrm{k}\right) \\
0.04 \mathrm{~m} \\
0.38 \mathrm{~m}^{3} / \mathrm{m}^{3} \\
20{ }^{\circ} \mathrm{C}\end{array}$ \\
\hline
\end{tabular}

表 1 設計条件

\begin{tabular}{|c|c|c|c|}
\hline コレクターの種類 & Type A & Type B & Type C \\
\hline$F^{\prime} K_{c u l}\left[\mathrm{~W} /\left(\mathrm{m}^{2} \cdot \mathrm{K}\right)\right]$ & 3.37 & 5.42 & 7.44 \\
\hline$F^{\prime}(\tau \alpha)_{e}[-]$ & 0.76 & 0.68 & 0.65 \\
\hline 集熱板 & 選択吸収面 & 黒色塗装 & 黒色塗裝 \\
\hline 集熱方式 & 裏面集熱 & 裹面集熱 & 表面集熱 \\
\hline
\end{tabular}

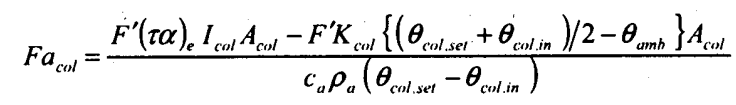

シミュレーションに用いたコレクターの特性係数とその仕様を表 2 に示した。これらの特性係数は, 田中等 ${ }^{4)}$ の実験結果の図から読 み取った值である。ここでは, 集熱風量, 長波長放射および日射の コレクター面への入射角度の影響は無視し, 定数と仮定している ${ }^{2)}$.

\section{(b) 砕石蓄熱槽}

砕石蓄熱槽の伝熱モデルには, Schumannによって提案されたモデ ルを用いた. Schumann モデルずは以下の仮定に基づいている.

（1）蓄熱材として小径の砕石を想定しているので, 個々の砕石内部 の温度は一様である。

（2）槽内空気は一次元流れであり，流速分布は断面全体にわたって 一様である.

さらに, Schumann モデルの蓄熱槽内空気の熱収支式について, 空 気の熱容量は砕石に比べ十分小さいのでこれを無視し，熱伝導によ る砕石蓄熱槽内の熱拡散を無視できるとすると, 蓄熱槽内空気およ び砕石の熱収支式は，式(4)，式(5)となる ${ }^{6)}$.

$$
\begin{gathered}
c_{a} \rho_{a} F a_{s t} \frac{\partial \theta_{s t, a}}{\partial x}=h_{v} A_{s t}\left(\theta_{s t, s}-\theta_{s t, a}\right) \\
c_{s} \rho_{s} A_{s t}(1-f) \frac{\partial \theta_{s t, s}}{\partial t}=h_{v} A_{s t}\left(\theta_{s t, a}-\theta_{s t, s}\right)
\end{gathered}
$$

ここで, 体積熱伝達率 $\left(h_{v}\right)$ には, Coutier 等の実験式 ${ }^{7)}($ 式(6))を用 いた。

$$
h_{v}=700\left(\frac{F a_{s t} \rho_{a}}{A_{s t} d_{e}}\right)^{0.76}
$$

一日の蓄熱量 $\left(Q_{c}\right)$ は, 集熱終了時の蓄熱槽内砕石温度 $\left(\left.\theta_{s t s}\right|_{t=\text { lend }}\right)$ か ら, 蓄熱槽内空気の熱容量を無視できるものとして, 次式を用いて 計算した。

$$
Q_{c}=c{ }_{s} \rho_{s}(1-f) A_{s t} \int_{0}^{H_{s t}}\left(\left.\theta_{s t, s}\right|_{t=t_{r e t}}-\theta_{o}\right) d x
$$

\section{2 計算条件および計算方法}

本論文で検討している太陽熱暖房システムは, 変風量・定温度集 
熱方式としているので, 集熱用ファンは, 集熱温度が設定値となる ようにインバータにより制御されるとし，その制御下限值を風量の 上限値の $30 \%$ とした，集熱風量の上限値は，コレクター入口空気温 度 $\left(\theta_{\text {col.in }}\right)$ が蓄熱槽初期温度 $\left(\theta_{o}\right)$ であり，コレクター面への日射量が 最大值となるときに, 集熱温度が集熱設定温度となる風量とし, 次 式により求めた。

$$
\left.F a_{c o l}\right|_{\text {max }}=\frac{\left.F^{\prime}(\tau \alpha)_{e} I_{c o l}\right|_{\text {max }} A_{c o l}-F^{\prime} K_{c o b}\left\{\left(\theta_{c o l, s e t}+\theta_{o}\right) / 2-\theta_{a m b}\right\} A_{c o l}}{c_{a} \rho_{a}\left(\theta_{c o t, s e t}-\theta_{o}\right)}
$$

式(3)で求めた集熱風量が制御範囲外の場合には, 式(3)の集熱風 量を集熱風量の上限値または下限值 $\left(F a_{\text {col. }}\right)$ として, コレクター出口 空気温度について整理した次式により集熱温度を求めた。

$$
\theta_{c o l, o u t}=\frac{\left(c_{a} \rho_{a} \frac{F a_{c o l, l}}{A_{c o l}}-\frac{F^{\prime} K_{c o l}}{2}\right) \theta_{c o l, i n}+F^{\prime}(\tau \alpha)_{e} I_{c o l}+\theta_{a m b} F^{\prime} K_{c o l}}{c_{a} \rho_{a} \frac{F a_{c o l, l}}{A_{c o l}}+\frac{F^{\prime} K_{c a l}}{2}}
$$

集熱運転をする条件は、コレクター入口空気温度が集熱設定温度 よりも低く, 式(9)で集熱風量 $\left(F a_{\text {col.l. }}\right)$ を 0 としたときにコレクター の出口空気温度が集熱設定温度 $\left(\theta_{\text {col,sel }}\right)$ よりも高くなるときとした。 すなわち，コレクター面への日射量が式(10)を満たし、コレクター 入口空気温度が集熱設定温度よりも低いとき集熱することとした。

$$
I_{c o l}>\frac{F^{\prime} K_{c o l}\left\{\left(\theta_{c o l . s e t}+\theta_{c o t . \text {.in }}\right) / 2-\theta_{a m b}\right\}}{F^{\prime}(\tau \alpha)_{e}}
$$

一日の蓄熱量 $\left(Q_{c}\right)$ を求めるための集熱終了時の蓄熱槽内砕石温度 分布は，式(4)と式(5)を前進型有限差分法により求めた。砕石蓄熱 槽を空気の流れ方向に 100 分割, 時間の差分刻み $(\Delta t)$ は, 式(11)で 求められる值とした。

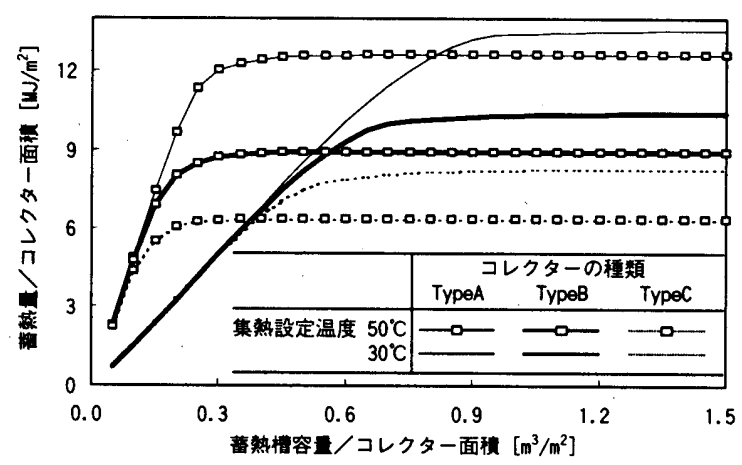

図 2 シミュレーションによるコレクター単位面櫴あたりの蓄熱 槽容量と蓄熱量の関係

$$
\Delta t=\frac{c_{s} \rho_{s}(1-f) V_{s t}}{c_{a} \rho_{a} F a_{c t l}} \times 10^{-7}
$$

この時間刻みは，次式で定義した無次元時間 $\left(t^{*}\right) て ゙ ，$ 単位無次元 時間を $10^{7}$ 分割するときの実時間刻みであり, 計算の安定性のため 槽容量が小さく風量が大きいほど差分時間刻みが小さくなるように している.

$$
t^{*}=\frac{c_{a} \rho_{a} \int_{0}^{t} F a_{c o l} d t}{c_{s} \rho_{s}(1-f) V_{s t}}
$$

砕石蓄熱槽入口空気温度（コレクター出口空気温度）および集熱 風量は,コレクターの入口空気温度が砕石蓄熱槽の出口空気温度に 等しいとして，コレクターのモデル式から求めた。

\section{3 計算結果と最適蓄熱槽容量}

図 2 は,コレクター単位面積あたりの一日の蓄熱量の計算結果で あり,コレクター単位面積あたりの蓄熱槽容量との関係を，集熱設 定温度毎に，性能の異なる 3 種のコレクターについて示している. この図はコレクター面積が $20 \mathrm{~m}^{2}$ の場合の結果であるが, コレクター 面積が異なる場合であってもほほ同様の結果が得られる。一般に, 蓄熱槽容量が大きくなるほど槽出口空気温度 (=コレクター入口空 気温度)が上昇し難くなるため, 平均集熱効率が高くなり蓄熱量が增 大するが, 槽出口空気温度は槽内初期温度 $\left(\theta_{o}\right)$ 以下にはならないの で, コレクターへの入口空気温度が常に槽内初期温度である場合の 積算集熱量以上には増大しない。この蓄熱量を以下では限界蓄熱量 と呼ぶ。また，集熱温度が低いほど蓄熱密度は低くはなるが、コレ クターの効率が高くなる条件で集熱するため, この限界蓄熱量は増 大することになる.

図 3 には，コレクターの出入口空気温度および集熱風量をコレク ター単位面積あたりの蓄熱槽容量が $0.10,0.25,0.50 \mathrm{~m}^{3} / \mathrm{m}^{2}$ の場合に

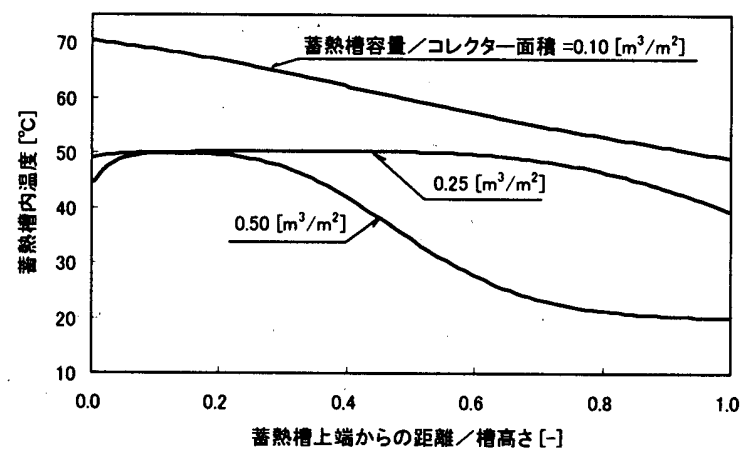

図4 集熱終了時の蓄熱槽内温度分布（コレクターの 種類:Type B, 集熱設定温度 : $50^{\circ} \mathrm{C}$ )

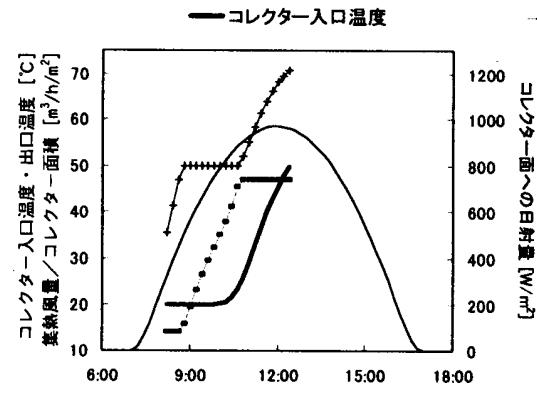

(a) $V_{\mathrm{at}} / \mathrm{A}_{\text {cot }}=0.10\left[\mathrm{~m}^{3} / \mathrm{m}^{2}\right]$

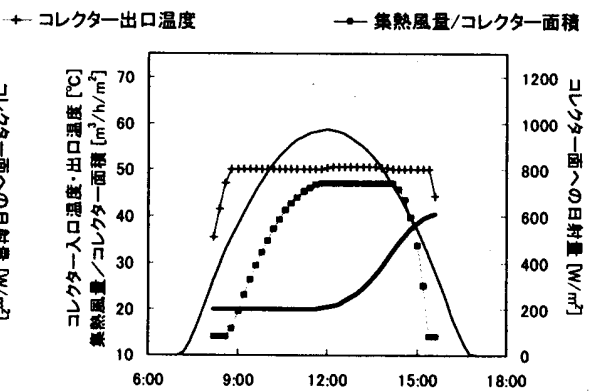

(b) $V_{\mathrm{s}} / A_{\text {col }}=0.25\left[\mathrm{~m}^{3} / \mathrm{m}^{2}\right]$

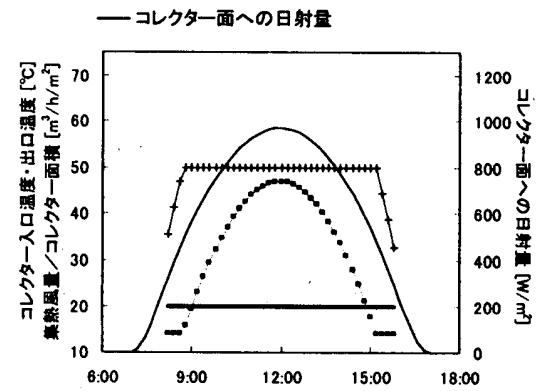

(c) $V_{\text {st }} / A_{c o t}=0.50\left[\mathrm{~m}^{3} / \mathrm{m}^{2}\right]$

図3 コレクター出入口空気温度およびコレクター単位面積あたりの集熱風量の日変化 （コレクターの種類: Type B, 集熱設定温度: $50^{\circ} \mathrm{C}$ ） 
ついて示しており，図 4 には，集熱終了時の槽内温度分布を，蓄熱 槽上端から下方への垂直距離を蓄熱槽高さで除した無次元距離を横 軸として示している。これらの図から，蓄熱槽容量が, $0.1 \mathrm{~m}^{3} / \mathrm{m}^{2}$ の 場合には，図 3(a)に示したように,コレクター入口空気温度(蓄熱 槽出口空気温度)の上昇が早く、日射量が十分あるにもかかわらず集 熱が早く終了することから，蓄熱槽容量が不足であると言える。ま た蓄熱槽容量が $0.50 \mathrm{~m}^{3} / \mathrm{m}^{2}$ の場合には, 図 4 から蓄熱槽下部の砕石 温度は初期温度にほほ等しく, 蓄熱槽を有効に利用できていないこ とが分かる。一方，蓄熱槽容量が $0.25 \mathrm{~m}^{3} / \mathrm{m}^{2}$ の場合には，一日の集 熱量は図 2 から上述の限界蓄熱量にほほ等しく，また図 4 から蓄熱 槽全体の温度が集熱温度でほほ一様であることから，この蓄熱槽容 量は限界蓄熱量を蓄熱するのに必要十分であると言える。

シミュレーション結果から，本論文では，限界蓄熱量をほほ蓄熱 できる最小の蓄熱槽容量を容量効率の観点から見た最適蓄熱槽容量 と定義する. 次章ではこの最適蓄熱槽容量を近似的に求めるための 関係式を導出し，その関係式を利用した簡易設計法を提案する。

\section{4 簡易設計法}

\section{1 集熱側システム}

最適蓄熱槽容量を近似的に求めるため，以下に示す蓄熱量につい ての二うの関係式を導出した。両式の導出にあたって，集熱風量に 制限は無く，集熱している間はコレクター出口空気温度は集熱設定 温度に等しいと仮定した。

[槽容量が最適蓄熱槽容量よりも十分に大きい場合の蓄熱量]

蓄熱槽容量が最適蓄熱槽容量よりも十分に大きい場合には，図 3 (c)に示したコレクター単位面積あたりの蓄熱槽容量が $0.5 \mathrm{~m}^{3} / \mathrm{m}^{2}$ の コレクター入口空気温度の日変化から分かるように, 集熱時はコレ クター入口空気温度が常に初期温度に等しいと仮定でき，コレクタ 一面への日射量が式(13)を満たす間は集熱できる。このときー日の 蓄熱量は集熱量に等しく，式(14)で表すことができる．この式(14) はコレクター性能と集熱設定温度に応じた限界蓄熱量を近似的に表 す式である。

$$
\begin{gathered}
I_{c o l}>\frac{F^{\prime} K_{c o l}\left\{\left(\theta_{c o l / s e t}+\theta_{o}\right) / 2-\theta_{a m b}\right\}}{F^{\prime}(\tau \alpha)_{e}} \\
Q_{c}=c_{a} \rho_{a}\left(\theta_{c o l / s e t}-\theta_{o}\right) \int_{t_{s}}^{t_{s}} F a_{c o l} d t
\end{gathered}
$$

[槽容量が最適蓄熱槽容量よりも十分に小さい場合の蓄熱量］ 一方, 蓄熱槽容量が最適蓄熱槽容量よりも十分小さい場合では, 図3(a)に示したように，蓄熱槽下部の砕石温度が集熱終了前に上昇 して,コレクター入口空気温度が上昇し、コレクター出口空気温度 を集熱設定温度に制御するために, 集熱風量が増大する。図 5 には, コレクター単位面積あたりの蓄熱槽容量が $0.1 \mathrm{~m}^{3} / \mathrm{m}^{2}$, 集熱設定温度 が $50^{\circ} \mathrm{C}$, コレクターの種類が Type B の場合で, 集熱風量に制限が 無く，集熱温度が常に集熱設定温度となる条件での蓄熱槽内砕石温 度と集熱風量の経時変化を示したここの図から，集熱終了直前には， 集熱風量が急増し，蓄熱槽の上端と下端の砕石温度がほほ等しく集 熱設定温度になっていることが分かる．理論的にも，コレクター入 口空気温度が集熱設定温度に等しくなるときには, 集熱風量は無限 大の值となり，集熱終了時に蓄熱槽内が一様に集熱設定温度になる と考えられる。このときの蓄熱量は，蓄熱槽の熱容量と蓄熱開始時
と終了時の温度差から次式で求められる。

$$
Q_{c}=c_{s} \rho_{s}(1-f)\left(\theta_{c c l s . s e t}-\theta_{s}\right) V_{s t}
$$

図 6 には，集熱設定温度が $40^{\circ} \mathrm{C}$ の場合について，シミュレーシ ヨンによる砕石蓄熱槽容量と一日の蓄熱量の関係および式(14) と式 （15）の計算結果を示した。この図から，式(14)と式(15)の交点とし て，それぞれの集熱温度での限界蓄熱量と容量効率的に最適な蓄熱 槽容量を近似的に得られることが分かる。ここで，槽容量が最適蓄 熱槽容量よりも小さい部分で，シミュレーションによる蓄熱量の値 が式(15)で求めた值よりも大きくなっているのは，集熱風量に上限 値を設け，集熱温度が集熱設定温度よりも高くなることを許容して いるためである.

さらに，式(14)と式(15)の交点として近似的に得られる最適蓄熱 槽容量は, 式(14) と式(15) から一日の蓄熱量 $\left(Q_{c}\right)$ を消去して, 蓄熱 槽容量 $\left(V_{s t}\right)$ を最適蓄熱槽容量 $\left(V_{o p t}\right)$ とした次式で表される.

$$
V_{v p t}=\frac{c_{a} \rho_{a} \int_{t_{s}}^{t_{s}} F a_{c v t} d t}{c_{s} \rho_{s}(1-f)}
$$

この式は，既報 ${ }^{2)} て ゙$ 示した定風量集熱の場合の最適蓄熱槽容量の 近似式を包含している式となっており，定風量集熱の場合は，集熱 風量の時間積分の項は集熱時間と集熱風量の積となる.

式(14)，式(16)の集熱風量にコレタター入口空気温度を蓄熱槽初 期温度とした式 (3)を代入し，一日の蓄熱量 $\left(Q_{c}\right)$ が, 本簡易設計法に よる太陽熱暖房システムで，蓄熱し，放熱できると見込む熱量 $\left(Q_{s}\right)$ (以下では蓄熱容量) と等しいとして解くと式(17), 式(18)となる. ここで, 式(17)はコレクター面積を, 式(18)は砕石蓄熱槽容量を求

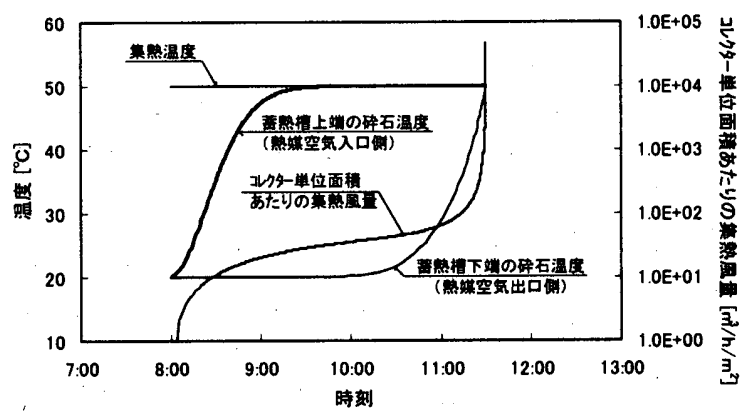

図 5 集熱風量に制御範囲の制限が無い場合の集熱風量と蓄熱 槽内砕石温度 $\left(V_{s t} / A_{c o l}=0.1\right.$, 集熱温度 $50^{\circ} \mathrm{C}$, コレクター Type B の場合)

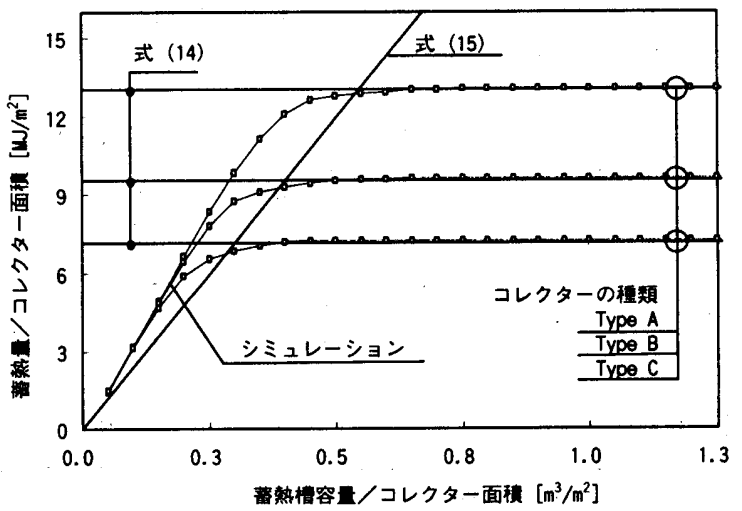

图6 シミユレーションによる碎石蓄熱槽容量と一日の蓄熱量の関 係および式(14)と式(15)の計算結果（集熱設定温度 $40^{\circ} \mathrm{C}$ ) 
めるための設計条件との関係式である.

$$
\begin{aligned}
& \frac{Q_{s}}{A_{c o l}}=\left\{\theta_{a m b}-\left(\theta_{c o l / . s e t}+\theta_{o}\right) / 2\right\} F^{\prime} K_{c o l}\left(t_{e}-t_{s}\right)+F^{\prime}(\tau \alpha)_{e} \int_{t,}^{t_{s} I_{c o l}} d t \\
& \frac{V_{o p t}}{A_{c o l}}=\frac{F^{\prime}(\tau \alpha)_{e} \int_{t_{1}}^{t_{t}} I_{c o l} d t+\left\{\theta_{a m b}-\left(\theta_{c o l . s e t}+\theta_{o}\right) / 2\right\} F^{\prime} K_{c o l}\left(t_{e}-t_{s}\right)}{c_{s} \rho_{s}(1-f)\left(\theta_{c o l, s e t}-\theta_{o}\right)}
\end{aligned}
$$

\section{2 放熱側システム}

放熱側システムで設計する值は，本簡易設計法では放熱用ファン の最大風量のみとし，タクトの設計とダクト等での圧力損失の計算 は別途行われるものとした，放熱最大風量は，蓄熱槽から放熱し， 室に吹出す空気温度が集熱設定温度に等しい場合に, 暖房負荷の最 大值をこのシステムで処理できる必要十分な吹出し風量とすれば, 次式を用いて算出できることになる.

$$
\left.F a_{h}\right|_{\text {max }}=\frac{\left.q_{h}\right|_{\text {max }}}{c_{a} \rho_{a}\left(\theta_{\text {col.,set }}-\theta_{o}\right)}
$$

この章で示した簡易設計法のまとめを表 3 に示した，表中の○印 は設計パラメータ等を決定するために必要な設計条件である。例え ば,コレクター面積は，設計条件として，集熱可能な時間，蓄熱容 量, 室設定温度, コレクターの特性, コレクタ一面日射量の集熱時 の積算值, 集熱設定温度, 集熱時平均外気温度が必要であり, 式(17) により算出することができる。

以下に設計手順を示す．(1)コレクター面日射量から，式(13)の不 等式を満たす時間 (集熱可能な時間)を求める. (2)集熱可能な時間， その間の積算日射量および設計条件から式(17)によりコレクター面 積を求める。 (3)砕石蓄熱槽容量を式(18)により求める。(4)集熱風量

\begin{tabular}{|c|c|c|c|c|c|c|}
\hline & \multicolumn{2}{|c|}{ 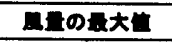 } \\
\hline & & & \multicolumn{2}{|c|}{ 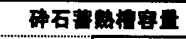 } & inget & 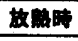 \\
\hline & & \multicolumn{2}{|c|}{ コレクター面表 } & 0 & 0 & \\
\hline \multicolumn{3}{|c|}{ 集盟可能な时間 } & 0 & $\mathrm{O}$ & & \\
\hline \multirow{8}{*}{$\begin{array}{l}\text { 設 } \\
\text { 咕 } \\
\text { 条 } \\
\text { 件 }\end{array}$} & 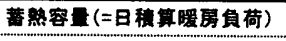 & & 0 & & & \\
\hline & 暖序負荷 & & & & & $\mathrm{O}^{* 1}$ \\
\hline & 室設定温度 & 0 & $\mathrm{O}$ & 0 & 0 & 0 \\
\hline & コレクターの特性 & 0 & 0 & 0 & $\mathrm{O}$ & \\
\hline & 䒠照措の容皘比熟 & & & 0 & & \\
\hline & コレクター面日射 & $\mathrm{O}^{\circ 2}$ & $\mathrm{O}^{* 3}$ & $\mathrm{O}^{* 3}$ & $\mathrm{O}^{* 1}$ & \\
\hline & 菓煮設定温度 & 0 & 0 & 0 & 0 & 0 \\
\hline & 聚舤時平均外视温度 & $\mathrm{O}$ & 0 & 0 & 0 & \\
\hline & 設竍に用いる関係式 & 式(13) & 式(17) & 式(18) & 式(8) & 式(19) \\
\hline
\end{tabular}
と放熱風量の最大値は，式(8)，式(19)により求める.

表 34 章での簡易設計法のまとめ

衰中の太年は設䑒パラメータ. ○印は設計パラメータ等を決定するために必要な設計条件

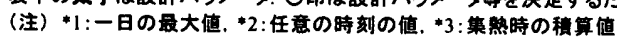

5. 蓄熱・放熱シミュレーション

ここでは，本簡易設計法により決定した設計值を用いて，蓄熱お よび放熱の繰返し運転のシミュレーションを行い, 周期的定常状態 の太陽熱暖房システムによる室への供給熱量を算出し，本簡易設計 法の妥当性と適用範囲について検討を行った。

5.1 放熱シミュレーションのモデルと計算方法

放熱シミュレーションでも，砕石蓄熱槽のモデルとして，3.1 で 示した伝熱モデルを用いた。このモデルでは，熱伝導による熱の垂 直方向への拡散や蓄熱槽からの熱損失, ファン停止時の蓄熱槽内の 㞬気の対流を無視しているので, 放熱停止時は, 蓄熱槽内の温度分 布は変化しないことになる。
室モデルは, 暖房時間帯は室温が $20^{\circ} \mathrm{C}$ 一定に保たれるものとし， 室から䂶石蓄熱槽への還り空気温度を室温の設定値の $20^{\circ} \mathrm{C}$ で一定 であるとした。ここで，室を $20^{\circ} \mathrm{C}$ に保つための暖房負荷を計算条 件として与え，この負荷を砕石蓄熱槽からの放熱と補助暖房により 賄うものとした．補助暖房の方法としては，居室に設置する強制对 流式の暖房器具を想定している。

放熱シミュレーションは, 蓄熱終了時の蓄熱槽内温度を初期条件 として, 放熱温度が設定室温 $+5^{\circ} \mathrm{C}\left(25^{\circ} \mathrm{C}\right)$ 以下となるか, 暖房時間が 終了するまで行い，放熱終了時と蓄熱終了時の蓄熱槽内温度の差か ら積算放熱量を求めた。蓄熱槽内温度は，蓄熱槽を空気の流れ方向 に 100 分割，時間の差分刻み $(\Delta t)$ は, $0.01 \mathrm{~s}$ として求めた。

暖房負荷 $\left(q_{h}\right)$ を処理できる放熱風量 $\left(F a_{h . t}\right)$ は, 放熱温度 $\left(\theta_{h}\right)$ (砕石 蓄熱槽出口空気温度)から, 次式で表される。

$$
F a_{h, l}=\frac{q_{h}}{c_{a} \rho_{a}\left(\theta_{\mathrm{h}}-\theta_{0}\right)}
$$

ここで，放熱用ファンもインバータにより制御されるとし，その 制御下限值を式(19)より求まる放熱風量の上限值の $30 \%$ とした。こ のときの，放熱風量 $\left(F a_{h}\right)$ および補助暖房熱量を表 4 に示した。

表 4 放熱風量と補助暖房熱量

\begin{tabular}{c|cc}
\hline & 放熱風量 $F a_{h}\left[\mathrm{~m}^{3} / \mathrm{s}\right]$ & 補助暖房熱量 $q_{s}[\mathrm{~W}]$ \\
\hline$F a_{h, 1}<0$ & 0 & $q_{h}$ \\
\hline $0<F a_{h, 1}<F a_{\left.h\right|_{\text {min }}}$ & $F a_{\left.h\right|_{\text {min }}}$ & 0 \\
\hline$F a_{h \mid \text { min }}<F a_{h, 1}<F a_{h \mid \text { max }}$ & $F a_{h, t}$ & 0 \\
\hline$F a_{\left.h\right|_{\text {max }}<F a_{h, t}}$ & $F a_{\left.h\right|_{\text {max }}}$ & $q_{h} \frac{F a_{\left.h\right|_{\text {max }}}}{F a_{h, t}}$ \\
\hline
\end{tabular}

ここで, $0<F a_{h . l}<\left.F a_{h}\right|_{\min }$ のとき, 単位時間あたりの太陽熱暖房シス テムからの供給熱量が, 暖房負荷を上回ることになるので, 放熱量 と暖房負荷が一致するように，差分計算時間ステップ $(\Delta t)$ 内で ON-OFF 制御されると考えて，太陽熱暖房システムを運転する時間 $\left(\Delta t_{r}\right) を\left(\Delta t_{r}=\Delta t F a_{h, l} /\left.F a_{h}\right|_{\text {min }}\right)$ として計算した。

\section{2 計算条件}

表 5 に, 蓄熱・放熱シミュレーションの条件を示した。システム の蓄熱容量 $\left(Q_{s}\right)$ は $100,200,400 \mathrm{MJ} の 3$ 通り, 暖房時間は, 夜間の 4 時間と翌朝の 2 時間の合計 6 時間，および夜間 6 時間と翌朝 3 時 間合計 9 時間の 2 通り，計算に用いた暖房負荷パターンは，図 $8 に$ 示したように 4 通りを設定し,さらに,それぞれの負荷パターンで, 設定負荷の最大值 (図中(3) と最小值 (図中(1))の比が 2:1, 3:1, 5:1 と なる場合を設定した。ささらに暖房負荷パターン T1 については夜間 と翌朝の負荷が等しい場合も含めて, 合計 26 通りの負荷パターンに ついて蓄熱・放熱シミュレーションを行った。暖房負荷パターンの $\mathrm{T} 1$ は夜間と翌朝のそれぞれの負荷が一定であり，T2 から T4 は蓄熱 負荷を考慮したものである。

\begin{tabular}{|c|c|}
\hline 暖房時間 & $\begin{array}{c}6 \text { 時間（夜間 } 4 \mathrm{~h} \text { ，䍿朝 } 2 \mathrm{~h} \text { ） } \\
9 \text { 時間（夜間 } 6 \mathrm{~h} \text { 翌朝 } 3 \mathrm{~h} \text { ) }\end{array}$ \\
\hline 蓄熱容量 & $100,200,400 \mathrm{MJ}$ \\
\hline コレクターの種類 & Type B \\
\hline 集熱設定温度 & $30,40,50,60^{\circ} \mathrm{C}$ \\
\hline
\end{tabular}

表 6, 表 7 には, 式(8)拉よ゙式(17)一式(19)を用いて算出した設 計値を示している．表 6 には，蓄熱容量が $100 \mathrm{MJ}$ の場合のコレク夕

表 5 蓄熱放熱シミュレーション条件 
(1) 設定暖房負荷の辰小值 $\left.\mathrm{q}_{\mathrm{h}}\right|_{\text {min }}$

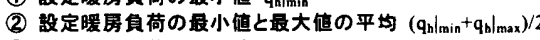

(3) 設定暖房負荷の最大檤 $\mathrm{q}_{\mathrm{b}} \mathrm{l}_{\max }$

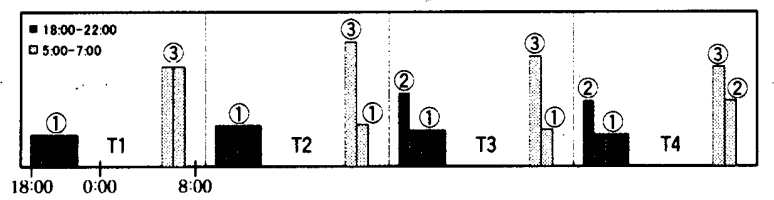

（a）暖房時間が 6 時間の負荷パターン

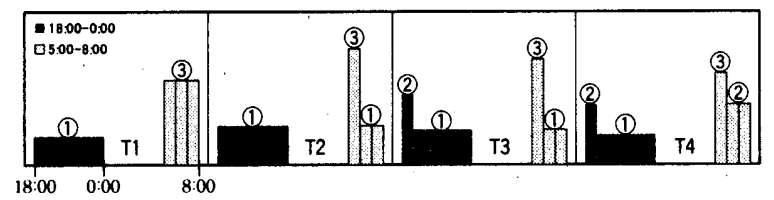

（b）暖房時間が 9 時間の負荷パターン

図 8 暖房負荷のパターン

一面積, 蓄熱槽容量および集熱風量の最大値を集熱設定温度毎に示 し, 表 7 には放熱風量の上限值を負荷パターン毎に示している.

蓄熱・放熱シミさレーションでは, 初期蓄熱槽内温度が室温設定 温度で一様であるとして, 蓄熱・放熱を繰り返してほほ周期的定常 状態となった 7 周期目の太陽熱暖房システムの一日の積算放熱量,

積算補助暖房熱量等を算出した。

\section{3 計算結果と考察}

図 9 には，蓄熱・放熱シミュレーションにより算出された，太陽 熱暖房システムからの積算放熱量の日積算暖房負荷に対する割合 (以下では充足率)を図示している。これは, 蓄熱容量を $100 \mathrm{MJ} と し ~$ た場合の，表 7 に示した全ての暖房負荷条件についての計算結果で ある。

蓄熱容量が積算暖房負荷に等しいとして設計したシステムでは, 暖房負荷の 90〜98\%程度しか賄うことができない. 充足率への影響 は, 設定した条件の範囲では集熱設定温度と負荷パターンの違いに よるものが比較的大きく，暖房時間と設定負荷の最大値と最小值の 比の影響は小さい，蓄熱容量が異なる場合でも同様の結果であり， 図10に示すように, 充足率が最大および最小となる暖房負荷条件は 同じであり，蓄熱容量が大きくなるほど充足率が若干大きくなるが, 蓄熱容量が $100 \mathrm{MJ}$ と $400 \mathrm{MJ}$ の間でも，最大で $1.5 \%$ 程度の差である.

充足率は, 集熱設定温度が高くなるほど低い値となるが,これは, 図 11 に示した槽内無次元温度分布の図から分かるように, 集熱設定 温度が高いほど, 集熱終了時の「(研石温度一室温)/(集熱設定温度 一室温)」で定義した無次元温度が低くなるからである。これは，同
表 6 簡易設計法による集熱側システムの設計パラメータの值” （設計用積算暖房負荷が $100 \mathrm{MJ}$ の場合）

\begin{tabular}{|c|c|c|c|c|}
\hline & \multicolumn{4}{|c|}{ 集熱設定温度 } \\
\hline & $30^{\circ} \mathrm{C}$ & $40^{\circ} \mathrm{C}$ & $50^{\circ} \mathrm{C}$ & $60^{\circ} \mathrm{C}$ \\
\hline コレクター面稙 $\left[\mathrm{m}^{2}\right]$ & 9.69 & 10.49 & 11.40 & 12.46 \\
\hline 碎石蕃熱槽容量 [ $\left.{ }^{3}\right]$ & 8.39 & 4.20 & 2.80 & 2.10 \\
\hline 集熱風量上限值 $\left[\mathrm{m}^{3} / \mathrm{h}\right]$ & 1,522 & 782 & 536 & 415 \\
\hline
\end{tabular}

表 7 暖房負荷条件ごとの放熱風量の最大值 （蓄熱容量が $100 \mathrm{MJ}$ で，集熱設定温度が $30^{\circ} \mathrm{C}$ の場合）

\begin{tabular}{|c|c|c|c|c|c|c|}
\hline \multirow{2}{*}{ 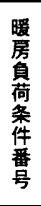 } & \multirow{2}{*}{ 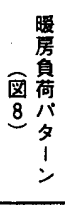 } & \multirow{2}{*}{$\begin{array}{l}\text { 暧 } \\
\text { 展 } \\
\text { 晆 } \\
\text { 間 } \\
\text { 异 }\end{array}$} & \multirow{2}{*}{ 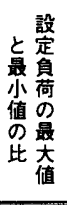 } & \multicolumn{2}{|c|}{ 䁔房負荷“ $[\mathrm{kW}]$} & \multirow{2}{*}{ 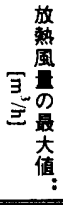 } \\
\hline & & & & 最大值 & 最小值 & \\
\hline 1 & T1 & \multirow{4}{*}{6} & \multirow{8}{*}{$2: 1$} & 6.94 & 3.47 & 2,073 \\
\hline 2 & $\mathrm{~T} 2$ & & & 7.94 & 3.97 & 2,370 \\
\hline 3 & T3 & & & 7.41 & 3.70 & 2,212 \\
\hline 4 & $\mathrm{~T} 4$ & & & 6.94 & 3.47 & 2.073 \\
\hline 5 & $\mathrm{TI}$ & \multirow{4}{*}{9} & & 4.63 & 2.31 & 1,382 \\
\hline 6 & $\mathrm{~T} 2$ & & & 5.56 & 2.78 & 1,659 \\
\hline 7 & $\mathrm{~T} 3$ & & & 5.29 & 2.65 & 1,580 \\
\hline 8 & $\mathrm{~T} 4$ & & & 4.83 & 2.42 & 1,442 \\
\hline 9 & $\mathrm{Tl}$ & \multirow{4}{*}{6} & \multirow{8}{*}{$3: 1$} & 8.33 & 2.78 & 2,488 \\
\hline 10 & T2 & & & 10.42 & 3.47 & 3,110 \\
\hline 11 & $\mathrm{~T}_{3}$ & & & 9.26 & 3.09 & 2.764 \\
\hline 12 & $\mathrm{~T} 4$ & & & 8.33 & 2.78 & 2,488 \\
\hline 13 & $T 1$ & \multirow{4}{*}{9} & & 5.56 & 1.85 & 1.659 \\
\hline 14 & $T 2$ & & & 7.58 & 2.53 & 2,262 \\
\hline 15 & T3 & & & 6.94 & 2.31 & 2,073 \\
\hline 16 & $\mathrm{~T} 4$ & & & 5.95 & 1.98 & 1,777 \\
\hline 17 & T1 & \multirow{4}{*}{6} & \multirow{8}{*}{$5: 1$} & 9.92 & 1.98 & 2,962 \\
\hline 18 & $\mathrm{~T} 2$ & & & 13.89 & 2.78 & 4,147 \\
\hline 19 & T3 & & & 11.57 & 2.31 & 3,456 \\
\hline 20 & T4 & & & 9.92 & 1.98 & 2,962 \\
\hline 21 & $\mathrm{TI}$ & \multirow{4}{*}{9} & & 6.61 & 1.32 & 1,975 \\
\hline 22 & $\mathrm{~T} 2$ & & & 10.68 & 2.14 & 3,190 \\
\hline 23 & T3 & & & 9.26 & 1.85 & 2,764 \\
\hline 24 & $\mathrm{~T} 4$ & & & 7.31 & 1.46 & 2,182 \\
\hline 25 & $\mathrm{~T} 1$ & 6 & \multirow{2}{*}{$1: 1$} & \multicolumn{2}{|c|}{$4.63($ - 定 $)$} & 1,382 \\
\hline 26 & $\mathrm{~T} 1$ & 9 & & \multicolumn{2}{|c|}{3.09 (一定) } & 921 \\
\hline
\end{tabular}

荎勢容量が $200 \mathrm{MJ}, 400 \mathrm{MJ}$ の場合は、この俥の 2 倍，4倍の值となる。

*集熱温度が異なる場合, この值の $1 / 2$ 倍 $\left(40^{\circ} \mathrm{C}\right), 1 / 3$ 倍 $\left(50^{\circ} \mathrm{C}\right), 1 / 4$ 倍 $\left(60^{\circ} \mathrm{C}\right)$ の值.

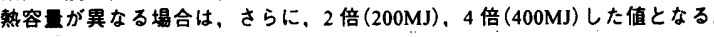

じ無次元温度差でも，集熱設定温度が高いほど外気温度と集熱時の コレクター内温度との差が大きくなるため, 熱損失が大きくなるた めである.

本研究では，ある想定した一日の集熱量で，その日の暖房負荷を すべて賄うことのできるシステムを前提としており，この前提を守 るためには, システムの規模を決定する式 $(17)$ 中の蓄熱容量 $\left(Q_{s}\right)$ は, 日積算暖房負荷よりも若干大きい值とすべきであることが分かる.

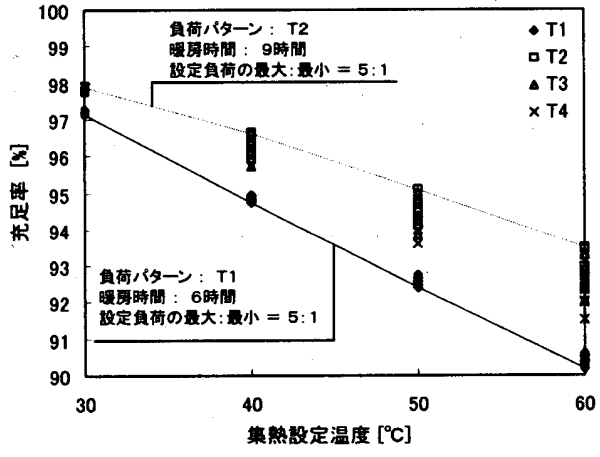

図 9 充足率（蓄熱容量 100MJ，表 7 の条件につい ての計算結果。図中実線は，最大值と最小値）

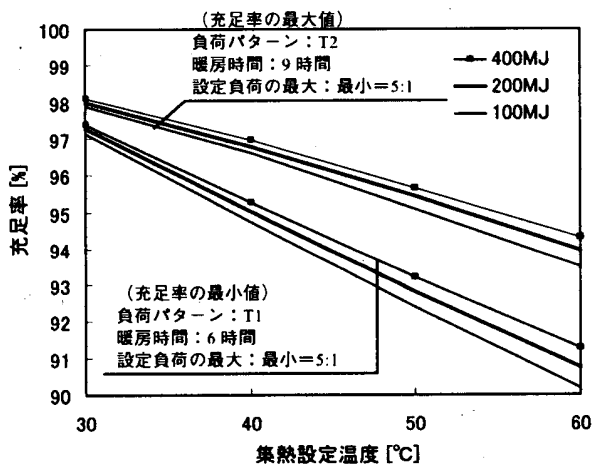

図 10 充足率の最大值と最小值

(蕃熱容量 $100 \mathrm{MJ}, 200 \mathrm{MJ}, 400 \mathrm{MJ}$ )

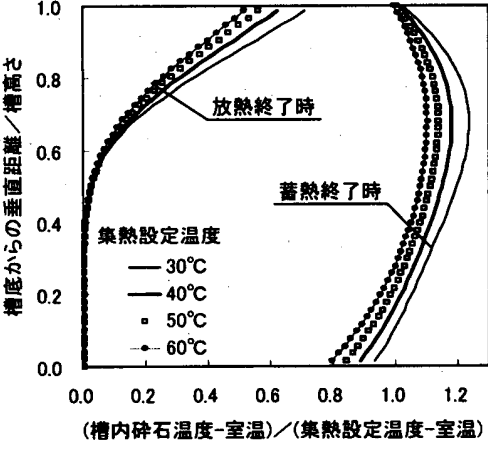

図 11 蓄熱槽内砕石無次元温度分布 （蓄熱容睤 $100 \mathrm{MJ}$, 負荷の最小值と最 大值の比 $1: 1$, 暖房時間 6 時間) 
表 8 計算条件

\begin{tabular}{|c|c|}
\hline 暖房負荷 & 表 7 で暖房負荷条件番号 25 の条件 \\
\hline 設定室温 & $18,20,22^{\circ} \mathrm{C}$ \\
\hline 集熱時の外気温度 & $0,5,10^{\circ} \mathrm{C}$ \\
\hline 集熱設定温度 & $30,40,50,60^{\circ} \mathrm{C}$ \\
\hline 蓄熱槽の形状（槽高さ：幅) & $0.5: 1 ， 2: 1 ， 5: 1$ (水平断面は正方形) \\
\hline コレクター面への日射量 & 表 1 の值の 0.7 倍, 1 倍, \\
\hline 蓄熱容量 & $50,100,300 \mathrm{MJ}$ \\
\hline $\begin{array}{l}\text { コレクターの特性 } \\
\left(F^{\prime} K_{c o l} / F^{\prime}(\tau \alpha)_{e}\right)\end{array}$ & $\begin{array}{l}3.37 / 0.76 \text { (Type A), } 5.42 / 0.68(\text { Type B) } \\
7.44 / 0.65(\text { Type C) }\end{array}$ \\
\hline
\end{tabular}

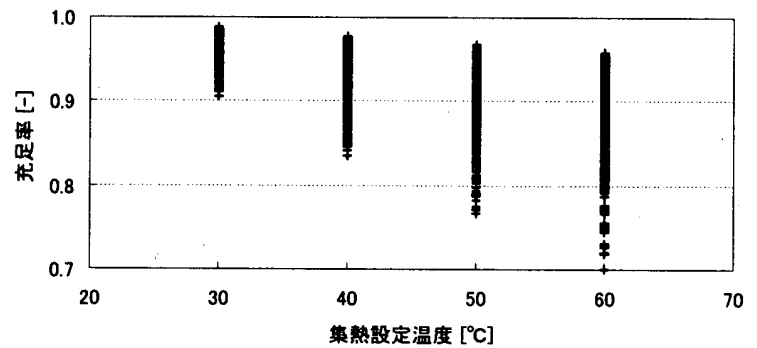

図 12 充足率 (表 8 に示した条件の全ての組み合わせつについ ての計算結果)

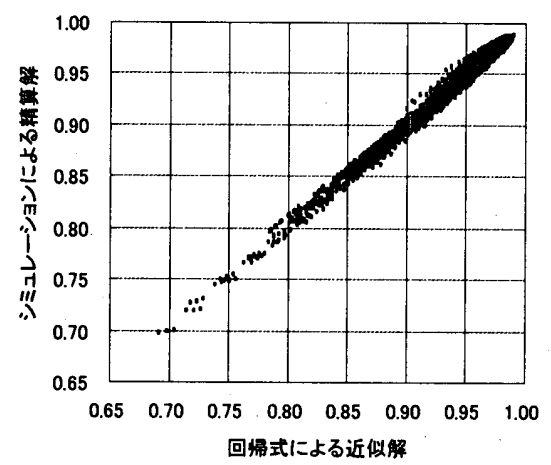

図 13 充足率の回帰式による近似解と精算解の比較

\section{4 システムの蓄熱容量}

設定室温, 外気温度, 蓄熱槽の形状, コレクターの特性等の充足 率に与える影響を調べ，蓄熱容量として設定すべき值と積算暖房負 荷の関係の検討を行う。ここでは，表 8 に示した条件の全ての組み 合わせ $(1,944$ 通り)について, 前述の蓄熱・放熱シミュレーション と同様にほほほ周期的定常状態になる 7 周期目まで蓄放熱を繰返し， 最終周期の計算結果から充足率を求めた。ここで，負荷パターンが 充足率に与える影響は大きいが, 表 7 に示した負荷パターンのうち 充足率の低い条件(暖房負荷条件番号 25)について検討を行う.

図 12 には，充足率の計算結果を示している，定性的に充足率が低 くなる条件は，(1)集熱設定温度が高い，(2)コレクターの熱損失係 数が大きい，(3)コレクターの日射吸収率が小さい，(4) 日射量が小 さい，(5)外気温が低い，(6) 蓄熱槽の熱媒空気の流れ方向の長さが 短い等である。そこで，上記の定性的考察から回帰式の形を定め, 3 つの係数を修正パウエル法 ${ }^{8)}$ をいて同定し, 式(21)を得た。

$$
R_{\text {sol }}=1-\left(p_{1} H_{s t}^{-0.5}+p_{2}\right)\left(\theta_{c o l, s e t}-\theta_{o}+p_{3}\right) \frac{F^{\prime} K_{c l}\left(\theta_{c o l}, s e t-\theta_{a m b}\right)}{F^{\prime}(\tau \alpha)_{e} I_{c o l, c v e}}
$$

ここで, 回㷌式の係数は, $p_{I}=8.50 \times 10^{-4}, p_{2}=5.02 \times 10^{-4}, p_{3}=74.2$, 説 明変数は, 蓄熱槽の熱媒空気の流れ方向の長さ $\left(H_{s t}\right)$, 集熱設定温度 $\left(\theta_{\text {col.set }}\right)$, 設定室温 $\left(\theta_{o}\right)$, コレクターの特性係数 $\left(F^{\prime} K_{c l}, F^{\prime}(\tau \alpha)_{e}\right)$, コレ クター面へ入射する平均日射量 $\left(I_{\text {col.ave }}\right)$ および集熱時の平均外気温 度 $\left(\theta_{a m n}\right)$ である。

図 13 は,式(21)による近似解とシミュレーションによる精算解を 示している. 結果から, 表 8 に示した設計条件の範囲内では, 式 $(21)$ により， $\pm 2 \%$ 以内の誤差で充足率を予測できることがわかる．

システムの蓄熱容量 $\left(Q_{s}\right)$ は，日積算暖房負荷 $\left(Q_{h}\right)$ を蓄熱容量に等 しいとして設計したシステムの充足率 $\left(R_{s o l}\right)$ を式 $(21)$ により算出し, この充足率で日積算暖房負荷を除した值となる.このことから, 式 （17）を日積算暖房負荷と式 (21)で得られる充足率を用いて表すと式 (22)となる.

$$
\frac{Q_{h}}{A_{c o l}}=R_{s o l l}\left\{\left(\theta_{a m b}-\frac{\theta_{o s}+\theta_{c o l, s e t}}{2}\right) F^{\prime} K_{c o l}\left(t_{e}-t_{s}\right)+F^{\prime}(\tau \alpha)_{e} \int_{t_{s}}^{t_{c}} I_{c o l l} d t\right\}
$$

この補正によって,コレクター面積は，4 章で示した簡易設計法 による設計値の $1 / R_{\text {sol }}$ 倍となる。これに伴って，砕石蓄熱槽容量と 集熱時の最大風量も同様に $1 / R_{s o l}$ 倍となる。またこのことは設計 条件としての暖房負荷が $1 / R_{\text {sol }}$ 倍になることに相当するので, 放熱 用ファンの最大風量も，充足率により次式で補正する。

$$
\left.F a_{h}\right|_{\text {max }}=\frac{1}{R_{\text {sol }}} \frac{\left.q_{h}\right|_{\text {max }}}{c_{a} \rho_{a}\left(\theta_{c o t / . s e t}-\theta_{o}\right)}
$$

\section{5 簡易設計法のまとめ}

本論文で提案する簡易設計法のまとめを表 9 に示す．本簡易設計 法により, 表 9 に示した設計条件（暖房負荷, 室設定温度, コレク ターの特性, 砕石蓄熱槽の容積比熱, 蓄熱槽の高さ,コレクター面 日射量, 集熱設定温度, 集熱時平均外気温度）から, 表中に太字で 示したコレクター面積，砕石蓄熱槽容量および集熱時と放熱時の風 量の最大值を求めることができる。

以下に具体的な設計手順を示す．(1)コレクター面日射量から，式 （13）の不等式を満たす時間（集熱可能な時間）を求める。(2)集熱可 能な時間と設計条件から，式(21)により充足率を求める. (3)集熱可 能な時間，充足率および暖房負荷などの設計条件から式(22)により コレクター面積を求める。（4)コレクター面積等から砕石蓄熱槽容量 を式(18)により求める。（5)集熱風量および放熱風量の最大値は，式

\begin{tabular}{|c|c|c|c|c|c|c|c|}
\hline & & & & & & nq & 大大偣 \\
\hline & & & & 啸石䊅 & 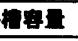 & 整些时 & 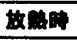 \\
\hline & & & コレ & 一面䖯 & 0 & 0 & \\
\hline & & & 充足事 & 0 & & & 0 \\
\hline & 集莇可 & 气な時間 & 0 & 0 & $\mathrm{O}$ & & \\
\hline & 暖房負荷 & & & $\mathrm{O}^{* 1}$ & & & $\mathrm{O}^{* 2}$ \\
\hline & 室設定温度 & 0 & 0 & 0 & 0 & 0 & 0 \\
\hline 钤 & コレクターの特性 & 0 & 0 & 0 & 0 & 0 & \\
\hline 斯 & 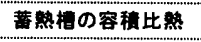 & & & & 0 & & \\
\hline 条 & 蕃慜槽の高さ & & 0 & & & & \\
\hline 件 & コレクター面日射量 & $\mathrm{O}^{* 3}$ & $0^{* 4}$ & $\mathrm{O}^{* 4}$ & $\mathrm{O}^{* 4}$ & $\mathrm{O}^{.2}$ & \\
\hline & 集㥿設定温度 & 0 & 0 & 0 & 0 & 0 & 0 \\
\hline & 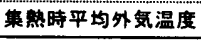 & 0 & 0 & 0 & 0 & 0 & \\
\hline & 殳垶に用いる関係式 & 式(13) & 式(21) & 式(22) & 式(18) & 式(8) & 式(23) \\
\hline
\end{tabular}
(8)，式(23)により求める.

表 9 簡易設計法のまとめ

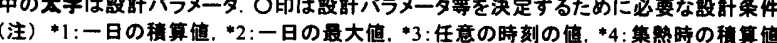




\section{6. まとめ}

砕石蓄熱槽を有する空気集熱式太陽熱暖房システムについて，合 理的な最適設計のための簡易設計法について検討を行った。

最初に蓄熱のシミュレーションを行い；その結果から集熱設定温 度に応じた限界の蓄熱量をほほ蓄熱できる最小の蓄熱槽容量を最適 蓄熱槽容量であると定義し，理論的検討からこの最適蓄熱槽容量を 近似的に求める方法を示し，設計条件と暖房負荷に見合ったシステ ムの蓄熱容量から,コレクター面積と蓄熱槽容量を求めるための関 係式を示した。

次にこの関係式を利用した簡易設計法を提案し：これにより決 定した設計値を用いて，蓄熱・放熱の繰返し運転のシミュレーショ ンを行い，本簡易設計法の適用範囲について検討を行った。その結 果, 設計条件を説明変数とした回帰式をシステムの蓄熱容量の補正 式として使用することで，現実的な設計条件の範囲内では十分適切 な設計ができることを示した。

\section{鱾易}

\begin{tabular}{|c|c|}
\hline$A_{c o l}$ & : コレクター集熱面面積 \\
\hline$A_{s t}$ & ：蓄熱槽の断面積 。 \\
\hline$c_{a}$ & : 空気の比熱 \\
\hline$c_{s}$ & : 砕石の比熱 \\
\hline$d_{e}$ & : 砕石の等価直径 \\
\hline$f$ & : 蓄熱槽の空隙率 \\
\hline$F a_{c n l}$ & ：集熱風量 \\
\hline$F a_{\text {coll. }}$ & ：集熱風量の制御下限値または上限值 \\
\hline$F a_{s t}$ & : 蓄熱槽を通過する風量 \\
\hline$F a_{h, t}$ & : 暖房負荷に忍じた放熱風量 \\
\hline$F a_{h}$ & ：制御範囲を考虐した放熱風量 \\
\hline$F^{\prime}$ & : 集熱器効率因子 \\
\hline$h_{v}$ & : 砕石と空気の間の体塩熱伝達率 \\
\hline$H_{s t}$ & ：蓄熱槽の高さ。 \\
\hline$I_{c o l}$ & : コレクターに入射する日射量： \\
\hline$I_{\text {collane }}$ & : コレクターに入射寸る平均日射量 \\
\hline$K_{c o l}$ & : コレクターの熱損失係数 \\
\hline$t_{\mathrm{star},} t_{\mathrm{s}}$ & ：集熱開始時刻 \\
\hline
\end{tabular}

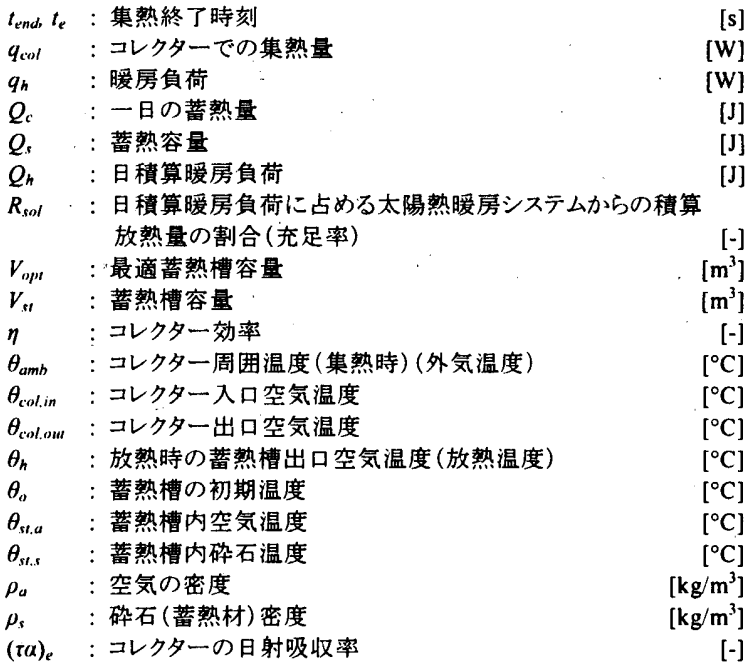

\section{参考文献}

1) Duffie A.J. and Beckman W.A : Solar engineering of thermal processes, John Willey \&Sons, pp.485-511, 1980

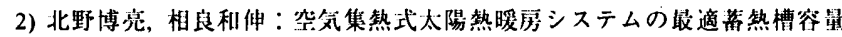
に関する理論的検討，日本建築学会計画系論文集，第 532 号，pp.29-35， 2000.6

3) 松尾陽, 他 17 名, 日本太陽エネルギー学会, 新太陽エネルギーハンドブ ック, 初版, pp.1 42,141, 142, 2000

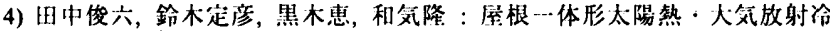
却装置に関する研究その 4 各種空父集熱器の笑験, 目本建築学会大会 学術講演梗概集, pp.569-570, 1982

5) Schumann T. E.W. : Heat transfer: A Liquid flowing through a porous prism, J. Franklin Inst. 208, pp.405-416, 1929

6) Sagara K. and Nakahara N.: Thermal Performance and Pressure Drop of Rock Beds with Large Storage Materials, Solar Energy, Vol.47 No.3, pp.157-163, 199

7) Coutier J.P. and Farber E.A.: Tow Applications of a Numerical Approach of Heat Transfer Process within Rock Beds, Solar Energy, Vol.29, pp.451-462, 1982

8) 款納秀明：システムの最適理論と最適化, コロナ礼, 1987 